\title{
Feeding ecology of immature Lithodoras dorsalis (Valenciennes, 1840) (Siluriformes: Doradidae) in a tidal environment, estuary of the rio
}

\author{
Amazonas \\ Thiago Augusto Pedroso Barbosa ${ }^{1}$, Ronaldo Borges Barthem² and Luciano \\ Fogaça de Assis Montag ${ }^{1}$
}

\begin{abstract}
Studies of feeding ecology are important for the evaluation of interactive processes in fish communities. This study evaluated the feeding ecology of Lithodoras dorsalis (Doradidae) from streams within the Amazon estuary delta (Brazil), a macro-tidal area, on different pluviometric periods. A total of 371 young specimens was collected during 12 months of sampling (July 2010 to June 2011). The species diet was composed of 28 food items analyzed by Repletion Index, Alimentary Index and Niche Breadth. Young L. dorsalis was classified as herbivore with a frugivory tendency due to the high importance of fruit and seeds in its diet. Food intake varied among sampled months, with the lowest intake being recorded during the rainy-dry season transition period, and the highest at the beginning of the dry season. The importance of food items and the composition of the diet were different throughout the year, probably due to the daily tides that allow fish to access new environments and the pluviometric periods. These results provide important data on the feeding ecology of Amazonian doradids. The study also emphasized the importance of allochthonous resources, derived from the riparian forest, which reinforces the importance of this habitat for the conservation of Neotropical freshwater fishes.

O estudo da ecologia alimentar de peixes é uma abordagem consistente na avaliação dos processos interativos dentro das comunidades. Dessa forma, este trabalho teve como objetivo investigar a ecologia alimentar do bacu-pedra Lithodoras dorsalis em furos próximos no delta do estuário Amazônico (Brasil), uma área sobre influência de macro-marés, em diferentes períodos pluviométricos. Durante 12 meses de coletas (julho de 2010 a junho de 2011), foram coligidos 371 espécimes jovens, sendo que a dieta da espécie foi composta por 28 itens alimentares analisados pelos seguintes índices: Índice de Repleção Estomacal, Índice de Importância Alimentar e Amplitude de Nicho. Lithodoras dorsalis quando jovem foi classificada como herbívora com tendência à frugivoria, devido aos altos valores de importância de frutos e sementes em sua dieta. A intensidade de obtenção de alimento por L. dorsalis diferiu entre os meses de coleta, onde o final do período de transição chuva-estiagem e o início da estiagem foram os períodos de menor e maior atividade alimentar, respectivamente. Também houve diferença na importância alimentar dos itens entre os períodos pluviométricos. Estes resultados fornecem informações importantes sobre a ecologia alimentar de doradídeos na Amazônia. Além disso, percebeu-se o alto consumo de material alóctone pelo bacu-pedra, sendo estes itens alimentares provenientes da floresta ripária, o que reforça a importância deste ambiente para a conservação da ictiofauna neotropical.
\end{abstract}

Keywords: Diet, Doradidae, Feeding Index, Rock-bacu, Thorny catfish.

\section{Introduction}

Studies of feeding ecology are of fundamental importance for the understanding of interactive processes in fish communities (Winemiller, 1989; Hahn et al., 1997; Abelha et al., 2001), including those involving habitat features. In the Neotropics, aquatic environments provide fishes with an ample variety of food items, ranging from invertebrates to fruit and fishes (Goulding, 1980; Lowe-McConnell, 1999). However, the abundance of these resources may vary considerably over the course of the year, reflecting seasonal fluctuations in rainfall levels or hydrological parameters (Junk, 1980). This limits the degree of ecological specialization of most fish species for a single type of food item. Given this, most Neotropical fish species are dietary generalists or opportunists (Lowe-McConnell, 1999), and present considerable versatility in response to fluctuations in food availability (Abelha et al., 2001; Correa \& Winemiller, 2014).

${ }^{1}$ Laboratório de Ecologia e Conservação, Instituto de Ciências Biológicas, Universidade Federal do Pará, Rua Augusto Corrêa, 01, Guamá, Caixa Postal 479, 66075-110 Belém, Pará, Brazil. (TAPB) tapbarbosa@gmail.com (corresponding author), (LFAM) montag@ufpa.br ${ }^{2}$ Museu Paraense Emílio Goeldi, Departamento de Zoologia (CZO), Ictiologia, Av. Perimetral, 1901, Terra Firme, 66077-530 Belém, PA, Brazil. barthem@superig.com.br 
The vegetation along the stream and rivers provide food and habitat for fish during the flooding period. The flooding may occur irregularly or seasonaly by the intense rainfall or daily by the tide (Junk, 1980; Barthem \& Schwassmann, 1994; Claro-Jr. et al., 2004; Junk et al., 2012). The rainy period influences also the phenology of growth and reproduction of plants, which may produce fruits in wet or dry season. Fruit and seeds may provide fishes with a valuable source of energy to overcome periods of reduced resource availability and specially to produce their lipid-rich eggs (Goulding, 1980). Fishes may change their diet in response to fluctuations in the abundance of specific resources between climatic seasons (Abelha et al., 2001; Novakowski et al., 2008). Species adapted to frugivory, for example, may be forced to shift the diet and consume leaves, flowers or other plants parts during certain periods, depending on plant phenology patterns and the characteristics of the fish species, such as its energetic demands and body size, among others (Chick et al., 2003; Anderson et al., 2011; Horn et al., 2011). Species such as açai berry (Euterpe oleracea Mart.), aninga (Montrichardia linifera (Arruda) Schott) and buriti (Mauritia flexuosa L.) are abundant on the tidal floodplain of the rio Amazonas mouth. They play a prominent role in the feeding ecology of frugivorous fishes due primarily to the fact that they have asynchronous fruiting periods, and thus provide resources throughout most of the year (Maia \& Chalco, 2002; Guimarães et al., 2004; Leão \& Carvalho, 2005).

The rock-bacu or bacu-pedra Lithodoras dorsalis (Valenciennes, 1840) is one of the largest thorny catfish (Siluriformes, Doradidae), reaching at least $90 \mathrm{~cm}$ fork length and $12 \mathrm{~kg}$ in weight (Goulding, 1980). The species occurs in northern South America in the Amazon estuary and neighboring coastal areas of French Guiana (Sabaj \& Ferraris-Jr., 2003) and it is exploited by the commercial and local fisheries in the Amazon mouth. Lithodoras dorsails eats fruits and seeds and plays a role in the seed dispersal processes (Goulding, 1980; Souza-Stevaux et al., 1994; Waldhoff et al., 1996; Pilati et al., 1999; Maia \& Chalco, 2002). This species was classified as omnivorous by Santos et al. (2004) and herbivorous by Santos et al. (2006), and consumes molluscs, aquatic insect larvae, fruits and seeds (Ringuelet et al., 1967; Santos et al., 2004, 2006).

The goal of this study was to investigate the diet shift throughout the year and the relative importance of food types in the diet of young Lithodoras dorsalis in the rio Amazonas estuary, an environment with daily tidal influence and marked pluviometric periods. The species foraging activity was expected to be higher during the rainy period due to the increase in habitats availability because of the greater range of variation in the river levels. This allows the fish to access new environments and resources daily, which does not occur in the dry season.

\section{Material and Methods}

Study Area. Data were collected in the municipality of Abaetetuba, in the confluence of the rio Tocantins and rio Pará, in Pará State, Brazil. Rio Pará receives part of the rio Amazonas discharge, wich contributes with suspended solids and high turbidity, changes in water level and current direction are directly related to the tidal effect (Sioli, 1984; Barthem \& Schwassmann, 1994). The average daily tidal range at Abaetetuba is less than $3 \mathrm{~m}$, but during the equinoxial spring tides and the full or new phases of the moon the tide amplitude reaches $4.0 \mathrm{~m}$ (Hida et al., 1999). The limnological caracteritics of the water change with the variation of the rio Tocantins discharge. The water is rather transparent during the high discharge period of the rio Tocantins and become turbid in the low discharge period, due to the influence of rio Amazonas waters (Sioli, 1984; Barthem \& Schwassmann, 1994).

The vegetation is defined as tidal floodplain vegetation with ombrophilous, broadleaved species, merged with palm trees like buriti tree (M. flexuosa) and açai berry tree (E. oleracea), the latter being a species of great economic importance for local populations (Machado, 2008). The fruiting period of E. oleracea is from July to November (Guimarães et al., 2004), while M. flexuosa fruits from March to August (Sampaio \& Carrazza, 2012).

The local climate can be classified as Af following the Köppen-Geiger classification, corresponding to the typical conditions of tropical rainforest ecosystems (Peel et al., 2007). Annual precipitation is approximately $2000 \mathrm{~mm}$ (Machado, 2008). The rainy season lasts from February to April, rain-drought from May to July, the dry season from August to November and drought-rain from December to January. These periods will be analyzed and related to the feeding of L. dorsalis. Mean temperature is $27^{\circ} \mathrm{C}$, ranging from $20^{\circ} \mathrm{C}$ to $35^{\circ} \mathrm{C}$ over the year. Relative humidity is high, around $85 \%$, varying normally between $81 \%$ and 90\% (Machado, 2008).

Sampling. Lithodoras dorsalis specimens were collected monthly over a year, between July 2010 and June 2011. Specimens were collected in the streams of Sirituba Island in Abaetetuba, Pará, Brazil (0141’13.6”S 4852' 48.8”W; Figure 1).

Weir fishing nets of aproximately $10 \mathrm{~m}$ in lenght, $3 \mathrm{~m}$ in height $\left(30 \mathrm{~m}^{2}\right.$ of area), with a between-knots mesh size of 3-6 cm, were used to capture specimens. These nets were set in the stream mouth at dusk (between 17:00 h and 19:00 h), depending on the tide, and removed at dawn (05:00-07:00 h). This period of the day was adopted to ensure the capture of individuals moving from the smaller rivers to the main channel during the low tide. Specimens were removed each two hours from the area using seine nets $(5 \mathrm{~m} \mathrm{x} 1 \mathrm{~m})$, and hand- or dip-nets.

The specimens captured were analised in laboratory conditions in the Federal Institute of Pará (Instituto Federal 
do Pará - IFPA), where they were weighed (total weight in grams $-\mathrm{W}_{\text {total }}$ ) and measured from the anterior extremity to the end of the spine (standard length in centimeters $\mathrm{L}_{\text {std }}$ ). A ventral-longitudinal incision was then made from the urogenital opening to the head for the removal of the stomach, which was weighed (grams) and emptied for the collection of its contents. The contents were weighed separately (grams) and then sorted in a Petri dish. Each distinct food item was identified using a stereomicroscope
(40 x), and weighted separetely. The gonads of each specimen were also removed for the definition of maturation phases.

Following evisceration, the specimens were fixed in $10 \%$ formaldehyde, conserved in $70 \%$ alcohol, and then incorporated into the ichthyological collection of Museu Paraense Emílio Goeldi (MCT/MPEG), under the following catalog numbers: MPEG19134; MPEG19202; MPEG19203; MPEG19610; MPEG19611; MPEG21668-MPEG21681.

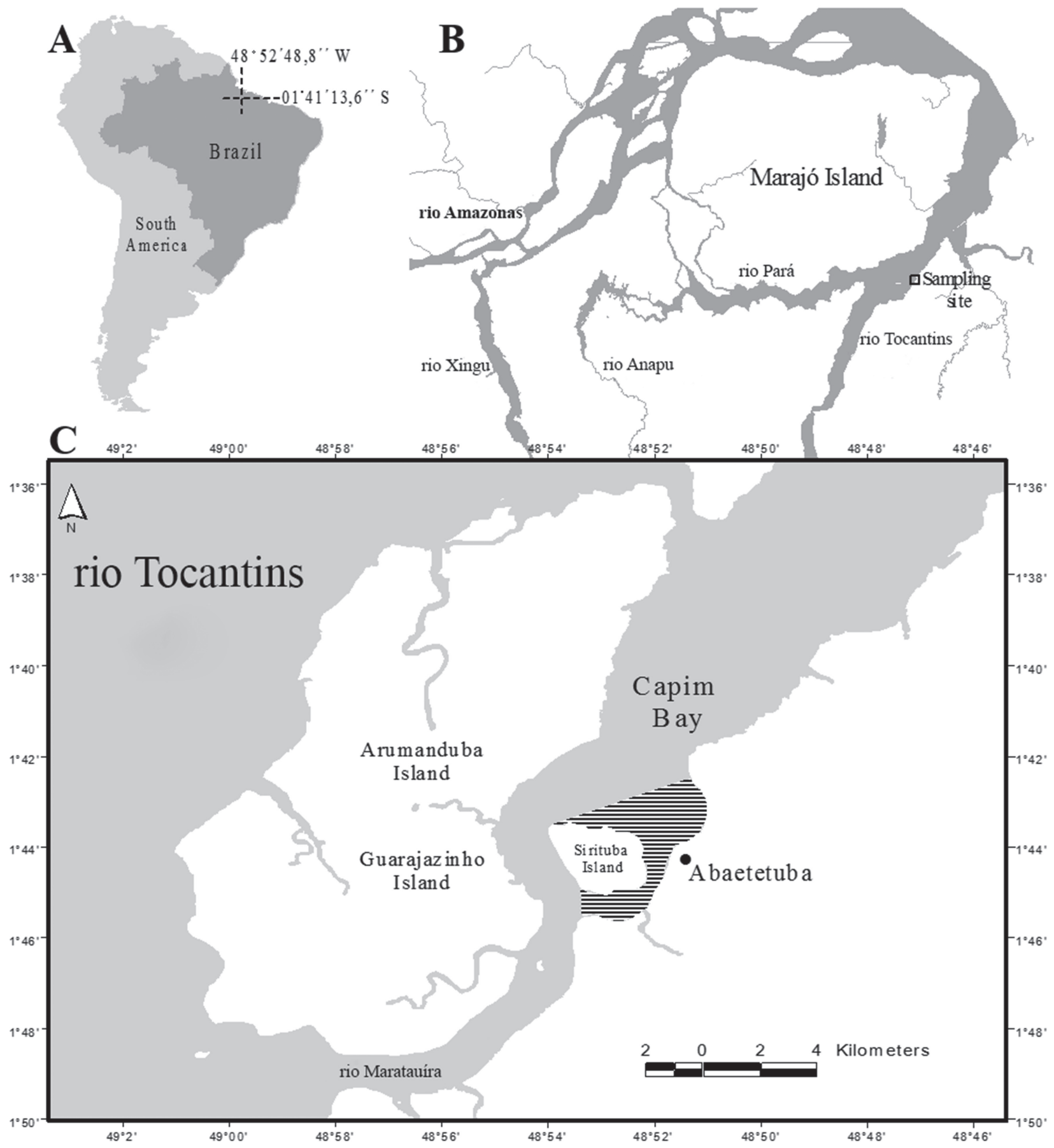

Fig. 1. Location of study area near the mouth of the rio Amazonas in Brazil. A, Location of Brazil on South America; B, rio Amazonas mouth with the sampling site; C, Study area (specimens were collected within the shaded area). 
Data analysis. The Lithodoras dorsalis diet composition was inferred by analyzing stomach contents. Each food item was initially classified as to its origin (allochthonous or autochthonous) and taxonomy. Prey was identified to the lowest possible taxonomic level, depending on the current digestion degree, with the assistance of specialists and appropriate literature (Ruppert et al., 2005; Costa et al., 2006).

The Repletion Index (RI\%; Zavala-Camin, 1996) was calculated to verify feeding activity levels. This parameter is obtained by $\mathrm{RI} \%=\left(\mathrm{W}_{\mathrm{i}} / \mathrm{W}_{\mathrm{t}}\right)$ * 100 , where: $\mathrm{W}_{\mathrm{i}}$ represents total items weight and $\mathrm{W}_{\mathrm{t}}$ total specimen weight. We used a Kruskal-Wallis nonparametric analysis of variance $(\mathrm{H})$, with a $5 \%$ significance level, to assess differences in food ingestion rates (RI\%) between pluviometric periods.

The relative contribution of different food items to the species' diet was assessed based on the Frequency of Occurrence ( $\mathrm{FO}_{i} \%$; Hyslop, 1980), the porcentage of stomachs in which each item occurred relative to total number of items, and on the Relative Weight (W\%; Hynes, 1950), the weight percentage of each item relative to the weight of all analysed food items (Hyslop, 1980; ZavalaCamin, 1996). $\mathrm{FO}_{\mathrm{i}} \%$ and $\mathrm{W} \%$ values were combined to estimate the Alimentary Index (AI $\%$, modified from Kawakami \& Vazzoler, 1980), which provides a measure of the importance of each food item. This index is calculated as $\mathrm{AI}_{\mathrm{i}} \%=\left(\mathrm{FOi} \% * \mathrm{~W} \% / \sum \mathrm{FOi} \% * \mathrm{~W} \%\right) *$ 100, where: $\mathrm{AI}_{\mathrm{i}} \%$ represents the food item $i$ alimentary index, $\mathrm{FO}_{\mathrm{i}} \%$ the item $i$ frequency of ocurrence and $\mathrm{W} \%$ the relative weight of item $i$. Empty stomachs were not considered for this analysis.

To assess the diet shift of L. dorsalis among pluviometric periods, the $\mathrm{AI}_{i} \%$ values recorded for each item in the different seasons were $\log (\mathrm{X}+1)$ transformed. The data were then analyzed using Nonmetric Multidimensional Scaling (NMDS) based on the Bray-curtis similarity index of the transformed data (Clarke \& Warwick, 2001). $\mathrm{AI}_{\mathrm{i}} \%$ values were evaluated using an Analysis of Similarity (ANOSIM), with a 5\% significance level. A Similarity Percentage Analysis (SIMPER; Clarke \& Warwick, 2001) was then performed to identify which items predominated in the different seasons.

Trophic niche breadth was calculated using Levin's standardized index in order to describe changes in the level of dietary specialization relative to pluviometric periods. This index varies from zero, when a species consumes a single type of food category, to one, when it consumes all available foods in equal amounts (Hulbert, 1978). The index is calculated by $\mathrm{Bi}=\left[\left(\sum \mathrm{jP}^{2} \mathrm{ij}\right)^{-1}\right](\mathrm{n}-1)^{-1}$, where: $\mathrm{Bi}$ is the standardized trophic niche; $\mathrm{Pij}$ is the ratio of the food category $j$ on species' $i$ diet; and $n$, the total number of food categories. To improve graphic visualization, the trophic niche breadth was calculated using month data, however the pluviometric periods were shown.

\section{Results}

During the 12 months of the study period, 371 specimens of sexually immature Lithodoras dorsalis were captured. The mean standard length of these specimens was $15.40 \mathrm{~cm}$ $(\mathrm{SD} \pm 4.87 \mathrm{~cm})$ and mean weight was $94 \pm 149.45 \mathrm{~g}$. Four of the specimens had empty stomachs, and were not included in the $\mathrm{AI}_{\mathrm{i}} \%$ analyses. The stomachs sample size per month and season are shown in Table 1.

Table 1. Number of stomachs sampled, per month and pluviometric periods, of Lithodoras dorsalis at the rio Amazonas mouth, Brazil, from July 2010 to June 2011.

\begin{tabular}{lc}
\hline \multicolumn{1}{c}{ Month/Period } & Number of stomachs sampled \\
\hline July/10 & 20 \\
August/10 & 40 \\
September/10 & 40 \\
October/10 & 30 \\
November/10 & 30 \\
December/10 & 30 \\
January/11 & 31 \\
February/11 & 25 \\
March/11 & 27 \\
April/11 & 37 \\
May/11 & 27 \\
June/11 & 34 \\
\hline Rain-Drought & 81 \\
Dry & 140 \\
Drought-Rain & 61 \\
Rainy & 89 \\
\hline Total & 371 \\
\hline
\end{tabular}

Foraging intensity, as measured by the Repletion Index (RI\%), varied significantly between seasons $\left(\mathrm{H}_{3.368}=17.81\right.$; $\mathrm{p}<0.05$ ). The dry season returned the lowest and the highest value RI\% $($ Median = 7.899; Max. $=23.084$ and Min. $=0$; Figure 2). Significant differences were also identified in the post-hoc multiple comparisons conducted for the KruskalWallis test (Table 2). In particular, the dry season was significantly different from rain-drought and rainy seasons, showing higher values.

A total of 28 food items were identified (Table 3), of which 16 were allochthonous and 12 autochthonous. In general, açaí fruit (E. oleracea) was the most important item in Lithodoras dorsalis diet ( $\left.\mathrm{AI}_{\mathrm{i}} \%=48.681 \%\right)$, followed by plant fragments $\left(\mathrm{AI}_{\mathrm{i}} \%=14.157 \%\right)$ and aninga $(M$. linifera $)$ $\left(\mathrm{AI}_{\mathrm{i}} \%=13.179\right)$. Per pluviometric periods, M. linifera was the main food item consumed in the drought-rain period $\left(\mathrm{AI}_{\mathrm{i}} \%=37.677 \%\right)$, E. oleracea in dry and drought-rain periods ( $\mathrm{AI}_{\mathrm{i}} \%=79.041$ and 44.871 , respectively) and plant fragments in the rainy season $\left(\mathrm{AI}_{i} \%=24.715\right)$. According to the Alimentary Index $\left(\mathrm{AI}_{\mathrm{i}} \%\right)$, L. dorsalis feeds mainly on plant material, in particular fruit and seeds. However, items such as brachyurans, decapods (Paleomonidae), and gastropods were also consumed (see Table 3 ). 


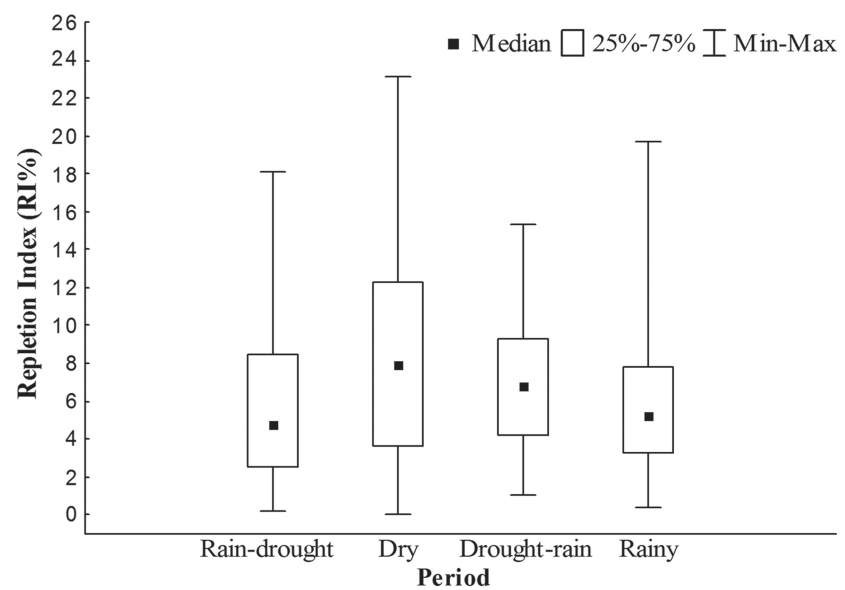

Fig. 2. Box-plot of Lithodoras dorsalis Repletion Index (RI\%) at the rio Amazonas mouth, Brazil, from July 2010 to June 2011.

Table 2. Probability values for pair-wise comparisons of the Repletion Index (RI\%) among pluviometric periods for the rock-bacu Lithodoras dorsalis, sampled in the rio Amazonas mouth region, Brazil. (*) Significant values.

\begin{tabular}{ccccc}
\hline & Rain-drought & Dry & Drought-rain & Rainy \\
\hline Rain-drought & & & & \\
Dry & $0.001^{*}$ & & & \\
Drought-rain & 0.195 & 1.000 & & \\
Rainy & 1.000 & $0.010^{*}$ & 0.543 & \\
\hline
\end{tabular}

The NMDS and ANOSIM analyses based on the Alimentary Index $\left(\mathrm{AI}_{\mathrm{i}} \%\right)$ of all items in the diet showed differences in the importance of food items in relation to pluviometric periods (ANOSIM: $\mathrm{R}=0.38 ; \mathrm{p}<0.05$ ) (Figure 3), with clear separation between dry and rainy seasons. The SIMPER analysis revealed that items such as M. linifera, E. oleracea, M. flexuosa and brachyura were responsible for differences among seasons (Table 4).

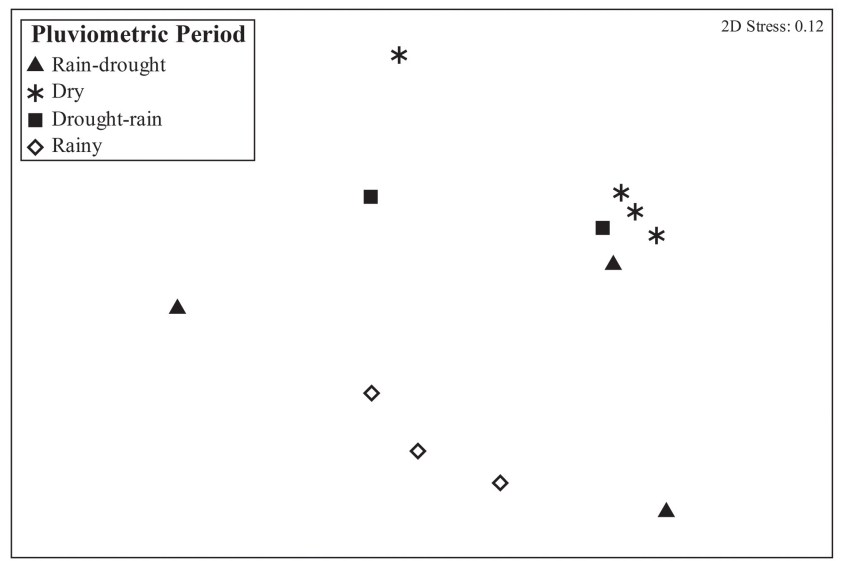

Fig. 3. Non-metric Multidimensional Scaling based on the Alimentary Index ( $\left.\mathrm{AI}_{\mathrm{i}} \%\right)$ of all food items consumed by the rock-bacu Lithodoras dorsalis among pluviometric periods, rio Amazonas mouth region, Brazil.
Table 3. Alimentary Index $\left(\mathrm{AI}_{\mathrm{i}} \%\right)$ per pluviometric period of food resources consumed by the rock-bacu Lithodoras dorsalis on the rio Amazonas mouth region, Brazil. (-) Represents the absence of the food item.

\begin{tabular}{|c|c|c|c|c|c|}
\hline Origin & Food Items & $\begin{array}{l}\text { Rain- } \\
\text { drought }\end{array}$ & Dry & $\begin{array}{l}\text { Drought- } \\
\text { rain }\end{array}$ & Rainy \\
\hline \multirow{16}{*}{ 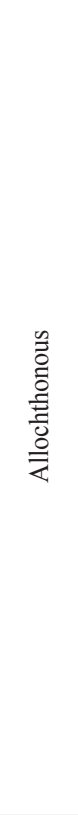 } & Formicidae & 0.001 & $<0.0001$ & $<0.0001$ & 0.001 \\
\hline & Isoptera & 0.014 & - & - & 0.003 \\
\hline & Diptera & - & - & - & 0.001 \\
\hline & Diplopoda & 0.001 & - & $<0.0001$ & $<0.0001$ \\
\hline & Arthropod Fragment & 0.002 & $<0.0001$ & 0.001 & 0.011 \\
\hline & Euterpe oleracea Mart. & 18.274 & 79.041 & 44.871 & 16.539 \\
\hline & Mauritia flexuosa Mart. & 0.846 & 1.187 & 11.617 & 13.029 \\
\hline & $\begin{array}{l}\text { Montrichardia linifera } \\
\text { (Arruda) Schott }\end{array}$ & 37.677 & 0.108 & 0.078 & 24.391 \\
\hline & Fruit fragments & 1.590 & 1.688 & 0.712 & 3.150 \\
\hline & Zea mays & - & $<0.0001$ & - & - \\
\hline & Anacardium occidentale L. & - & 0.001 & - & - \\
\hline & Spondias mombin L. & - & - & 0.090 & 0.019 \\
\hline & Mangifera indica $\mathrm{L}$. & - & - & 0.216 & - \\
\hline & Other plant fragments & 8.561 & 9.471 & 13.744 & 24.715 \\
\hline & Flowers & 0.455 & 0.107 & 0.038 & 0.102 \\
\hline & Leaves & 0.026 & 0.151 & - & - \\
\hline \multirow{15}{*}{ 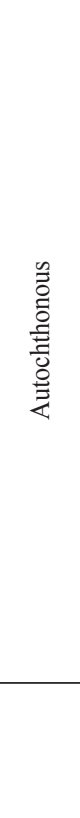 } & $\begin{array}{l}\text { Ucarapax and Armases } \\
\text { benedict }\end{array}$ & 11.125 & 3.196 & 11.125 & 10.928 \\
\hline & $\begin{array}{l}\text { Macrobrachyum } \\
\text { amazonicum }\end{array}$ & 0.127 & 0.183 & 0.048 & 0.133 \\
\hline & Gastropoda & 0.197 & 0.001 & 10.725 & 0.480 \\
\hline & $\begin{array}{l}\text { Paxyodon syrmatophorus } \\
\text { and Triplodon corrugatus }\end{array}$ & 0.304 & 0.004 & 1.273 & 0.343 \\
\hline & Sponges (Demospongiae) & - & - & - & $<0.0001$ \\
\hline & Chironomidae Larvae & $<0.0001$ & $<0.0001$ & - & - \\
\hline & Coleoptera Larvae & - & $<0.0001$ & 0.030 & 0.002 \\
\hline & Ciclorapha Larvae & - & $<0.0001$ & - & - \\
\hline & Ephemeroptera Nymph & - & $<0.0001$ & - & - \\
\hline & Oligochaeta & - & $<0.0001$ & - & - \\
\hline & Fish fragments & 0.001 & 0.022 & 0.001 & 0.009 \\
\hline & Algae & 2.174 & 0.120 & 0.581 & 1.131 \\
\hline & Digested organic material & 12.587 & 4.660 & 1.977 & 1.201 \\
\hline & Substrate & 6.038 & 0.001 & 0.261 & 2.192 \\
\hline & Minerals & $<0.0001$ & 0.059 & 2.612 & 1.620 \\
\hline
\end{tabular}

The trophic niche breadth showed low seasonal variation in resource use by Lithodoras dorsalis (Figure 4), since this index ranges from 0 to 1 and the highest value was 0.13 in January. This species has a specialist behavior tendency, with narrow niche breadth, mainly in the beginning of dry season, on 2010, and at the end of the drought-rain transition period, on 2011, due to the high consumption of acai E. oleracea $\left(\mathrm{AI}_{\mathrm{i}} \%=89.89 \%\right)$ and $M$. linifera $\left(\mathrm{AI}_{\mathrm{i}} \%=\right.$ $84.41 \%)$, respectively. 


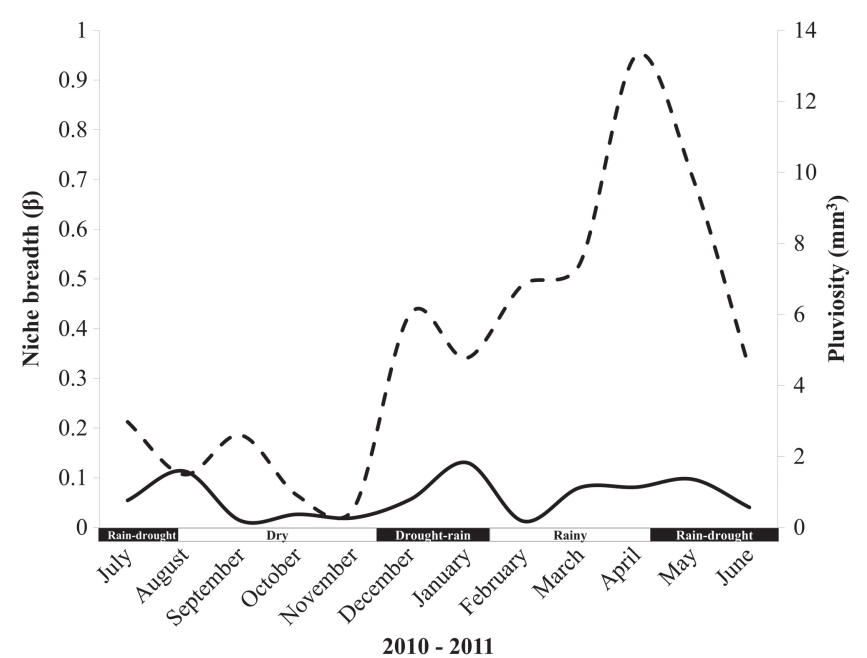

Fig. 4. Trophic niche breadth recorded for Lithodoras dorsalis on the rio Amazonas mouth, Pará, Brazil, from July 2010 to June 2011. The solid line represents the niche breadth values and the dashed line indicates mean pluviosity registered for the studied region.

Table 4. Percentage contribution of the main resources consumed by Lithodoras dorsalis at Abaetetuba, south of the rio Amazonas estuary (Brazil), during the different pluviometric seasons, based on the results of the SIMPER analysis.

\begin{tabular}{|c|c|c|}
\hline Period & Items & $\%$ of Contribution \\
\hline \multirow{3}{*}{ Rain-drought } & $\begin{array}{l}\text { Montrichardia linifera (Arruda) } \\
\text { Schott (Aninga) }\end{array}$ & $35.1 \%$ \\
\hline & Brachyura & $20.6 \%$ \\
\hline & Plant Fragment & $20.1 \%$ \\
\hline \multirow{3}{*}{ Dry } & Euterpe oleracea Mart. (Açai Berry) & $50.2 \%$ \\
\hline & Plant Fragment & $26.3 \%$ \\
\hline & Brachyura & $10.2 \%$ \\
\hline \multirow{3}{*}{ Drought-rain } & Euterpe oleracea Mart. (Açai Berry) & $27.3 \%$ \\
\hline & Mauritia flexuosa Mart. (Buriti) & $23.6 \%$ \\
\hline & Plant Fragment & $23.0 \%$ \\
\hline \multirow{3}{*}{ Rainy } & $\begin{array}{l}\text { Montrichardia linifera (Arruda) } \\
\text { Schott (Aninga) }\end{array}$ & $37.6 \%$ \\
\hline & Plant Fragment & $28.2 \%$ \\
\hline & Mauritia flexuosa Mart. (Buriti) & $21.6 \%$ \\
\hline
\end{tabular}

\section{Discussion}

The dominance of young individuals at the rio Amazonas mouth region is because the rock-bacu is a migratory fish with different feeding and reproductive sites. The rio Amazonas mouth is its nursery or growth area, and upstream sections of the rio Amazonas (including tributaries), the reproduction area (Goulding, 1980; Goulding et al., 1996; Barthem et al., 1991). Growth areas, essential for migrating species such as L. dorsalis, are sites where young individuals meet food and shelter needs all year long and are able to invest on body growth until attain sexual maturity, when they migrate to other regions (Goulding, 1980; Barthem et al., 1991). The rio Amazonas mouth has a high food availability, because most plant species fructify on different times, providing fruits and seeds for $L$. dorsalis almost all year long (Guimarães et al., 2004; Leão \& Carvalho, 2005; Sampaio \& Carrazza, 2012). In addition, because the water variation in the region is determined by the tides, fruits are accessible daily as they fall on the water surface (Barthem \& Schwassmann, 1994; Hida et al., 1999).

The high presence of fruits and seeds, like E. oleracea, $M$. linifera, $M$. flexuosa, highlights the importance of riparian forests as a substantial food source for Amazonian fishes (Goulding, 1980). Many studies demonstrate the importance of these food items for the ichthyofauna, as a consequence of its high energy level (Hahn et al., 1992; Waldhoff et al., 1996; Winemiller \& Jepsen, 1998; Claro-Jr. et al., 2004; Galetti et al., 2008; Pollux, 2011; Correa \& Winemiller, 2014). However, the variation in resource availability among pluviometric periods may modify species diet, where most fish species may alter their feeding behaviors according to changes in resource relative abundance (Abelha et al., 2001). The fish fauna of the Amazon basin present a number of specific adaptations to maximize the ingestion of energy according to major seasonal fluctuations in resource availability, for instance the opportunistic feeding behavior (Junk, 1985; Lowe-McConnell, 1999). This pattern was recorded for young $L$. dorsalis, here considered herbivore with a high frugivory tendency. The species fed mainly on fruits and seeds (almost $85 \%$ of total $\mathrm{AI}_{\mathrm{i}} \%$ ), according to the phenology of these plants, but also consumed items such as Crustacea and Gastropoda on different times of the year, based on the availability of these invertebrates on the environment. The herbivorous behaviour with high frugivory tendency of adult $L$. dorsalis was also observed by Goulding (1980) in the rio Madeira .

The preference for a given food item due to its availability may be explained by the Optimal Foraging Theory (MacArthur \& Pianka, 1966), which predicts that species will choose resources to combine high ease of capture with large amount of energy obtained. Therefore, during the year, species may present a specialist or generalist behaviour in obtaining food resources, depending on availability (Abelha et al., 2001; Wolff et al., 2009; Mazzoni et al., 2010; Masdeu et al., 2011; Correa \& Winemiller, 2014). Considering the low taxonomic variety of items ingested, L. dorsalis exhibited a behariour tending to specialist, eating principally fruits and seeds from the riparian forest, varying the species consumed probably according to availability. Futhermore, the presence of sediments in the stomach of Lithodoras dorsalis specimens indicates that the species also forages on the bottom, where it obtains the bivalves (mussels and oysters) consumed (Beasley, 2001; Hohn \& Costa, 2002). This type of foraging behavior has also been recorded in other doradid species (e.g., Hahn et al., 1997; Lowe-McConnell, 1999). Species of this family 
explores all environments searching for food, such as the surface to eat floating fruits, although it is adapted to live in river bottoms.

In view of the discussion above, food availability among pluviometric periods probably influenced $L$. dorsalis feeding intensity (RI\%) and its diet composition along the year at the rio Amazonas mouth. The different fructification periods among plant species influence which fruit is consumed during pluviometric periods, changing its foraging behavior (more or less specialist). In addition, the daily variation of water level due to tides is a factor that influences the availability of usable areas by fish populations (Morton et al., 1987; Krumme et al.; 2004, Stevens et al., 2010), since the daily flooding of riverbanks allows fishes to reach resources outside the main channel everyday. It does not occurs in environments influenced only by seasonal flood pulses; in such areas, fruits are available for fishes only during flooding periods, few months of the year (Goulding, 1980), or in sites where trees are near the river (Anderson et al., 2011; Horn et al., 2011). In conclusion, allochthonous items, especially those of vegetal origin, are important for Lithodoras dorsalis as a food source. It highlights the importance of riparian forest conservation at the rio Amazonas mouth, a key source of food resources for Neotropical fishes.

\section{Acknowledgments}

We thank to Coordenação de Aperfeiçoamento de Pessoal de Nível Superior (CAPES) for the scholarship (TAPB). The Conselho Nacional de Desenvolvimento Científico e Tecnológico (CNPq) provided LFAM with a research fellowship (process no. 301343/2012-8). The Instituto Federal do Pará, IFPA, Abaetetuba for the logistic support. We also thank the researches and professors M.Sc. Marta Coutinho (IFPA), Dr. José Birindeli (MZUSP), Dr. Cléverson Santos (MPEG), Dr. Rony Vieira (UFPA), Dr Roberta Valente (UFPA) and Dr Alba Lins (MPEG) for the help identifying the stomach contents of Lithodoras dorsalis, Dr. Leandro Juen (UFPA) and Dr. Bruno Spacek (UFPA) for the help with statistical analysis, Mr. Ilso, Jaime and Giovani for field assistance and Dr. Stephen F. Ferrari for his assistance with the english review.

\section{References}

Abelha, M. C. F., A. A. Agostinho \& E. Goulart. 2001. Plasticidade trófica em peixes de água doce. Acta Scientiarum, 23: 425434.

Anderson, J. T., T. Nuttle, J. S. S. Rojas, T. H. Pendergast \& A. S. Flecker. 2011. Extremely long-distance seed dispersal by an overfished Amazonian frugivore. Proceedings of the Royal Society B, 278: 3329-3335.

Barthem, R. B., M. C. L. de B. Ribeiro \& M. Petrere Jr. 1991. Life strategies of some long-distance migratory catfish in relation to hydroelectric dams in the Amazon basin. Biological Conservation, 55: 339-345.
Barthem, R. B. \& H. O. Schwassmann. 1994. Amazon River influence on the seasonal displacement of the salt wedge in the Tocantins River estuary, Brazil, 1983-1985. Boletim do Museu Paraense Emílio Goeldi. Série Zoologia, 10: 119-130.

Beasley, C. R. 2001. The impact of exploitation on freshwater mussels (Bivalvia: Hyriidae) in the Tocantins River. Brazil. Studies on Neotropical Fauna and Environment, 36: 159-165.

Chick, J. H., R. J. Cosgriff \& L. S. Gittinger. 2003. Fish as potential dispersal agents for floodplain plants: first evidence in North America. Canadian Journal of Fisheries and Aquatic Sciences, 60: 1437-1439.

Clarke, K. R. \& R. M. Warwick. 2001. Changes in marine communities: an approach to statistical analysis and interpretation. 2nd ed. Plymouth, PRIMER-E.

Claro-Jr, L., E. Ferreira, J. Zuanon \& C. Araújo-Lima. 2004. O efeito da floresta alagada na alimentação de três espécies de peixes onívoros em lagos de várzea da Amazônia Central. Brasil. Acta Amazônica, 34: 133-137.

Correa, S. B. \& K. O. Winemiller. 2014. Niche partitioning among frugivorous fishes in response to fluctuating resources in the Amazonian floodplain forest. Ecology, 95: 210-224.

Costa, C., S. Ide \& C. E. Simonka (Eds.). 2006. Insetos imaturos: metamorfose e identificação. Ribeirão Preto, Holos, 249p.

Galetti, M., C. I. Donatti, M. A. Pizo \& H. C. Giacomini. 2008. Big fish are the best: seed dispersal of Bactris glaucescens by the pacu fish (Piaractus mesopotamicus) in the Pantanal, Brazil. Biotropica, 40: 386-389.

Goulding, M. 1980. The fishes and the forest: explorations in Amazonian natural history. Berkeley, University of California Press, 280p.

Goulding, M., N. J. H. Smith \& D. J. Mahar. 1996. Floods of fortune: ecology and economy along the Amazon. New York, Columbia University Press, 193p.

Guimarães, L. A., T. M. Santos, M. D. Rodrigues \& B. H. de Frahan. 2004. A produção e comercialização do açaí do município de Abaetetuba, Pará. Pp. 159-179. In: Jardim, M. A. G., L. Mourão \& M. Groissmann. Açaí: possibilidades e limites para o desenvolvimento sustentável no estuário amazônico. Belém, Museu Paraense Emílio Goeldi. (Coleção Adolpho Ducke).

Hahn, N. S., A. M. Júnior, R. Fugi \& A. A. Agostinho. 1992. Aspectos da alimentação do armado, Pterodoras granulosus (Ostariophysi, Doradidae) em distintos ambientes do alto rio Paraná. Revista UNIMAR, 14 (Suplemento): 163-176.

Hahn, N. S., I. F. Andrian, R. Fugi \& V. L. L. Almeida. 1997. Ecologia trófica. Pp. 209-228. In: Vazzoler, A. E. A. M., A. A. Agostinho \& N. S. Hahn (Eds.). A planície de inundação do alto rio Paraná: aspectos físicos, biológicos e socioeconômicos. Maringá, Eduem.

Hida, N., J. G. Maia, M. Hiraoka, O. Shimm \& M. Nobuaki, 1999. River water level changes of the Amazon Estuary: at Breves, Caxiuanã and Abaetetuba. Manaus'99 - Hydrological and Geochemical Processess in Large Scale River Basins, p. 1-9.

Hohn, H \& M. L. da Costa. 2002. Ocorrência de ostras perlíferas no Marajó, rio Pará. Rem: Revista Escola de Minas, 55: 61-64.

Horn, M. H., S. B. Correa, P. Parolin, B. J. A. Pollux, J. T. Anderson, C. Lucas, P. Widmann, A. Tjiu, M. Galetti \& M. Goulding. 2011. Seed dispersal by fishes in tropical and temperate fresh waters: the growing evidence. Acta Oecologica, 37: 561-577.

Hulbert, S. H. 1978. The measurement of niche overlap and some of its relatives. Ecology, 59: 67-77. 
Hynes, H. B. N. 1950. The food of freshwater sticklebacks (Gasterosteus aculeatus and Pygosteus pungitius), with a review of methods used in studies of the food of fishes. Journal of Animal Ecology, 19: 36-58.

Hyslop, E. J. 1980. Stomach contents analysis - a review of methods and their application. Journal of Fish Biology, 17: 411-429.

Junk, W. J. 1980. Áreas inundáveis: um desafio para limnologia. Acta Amazonica, 10: 775-796.

Junk, W. J. 1985. Temporary fat storage, an adaptation of some fish species to the waterlevel fluctuations and related environmental changes of the Amazon River. Amazoniana, 9: 315-351.

Junk, W. J., M. T. F. Piedade, J. Schöngart \& F. Wittmann. 2012. A classification of major natural habitats of Amazonian white-water river floodplains (várzeas). Wetlands Ecology and Management, 20: 461-475.

Kawakami, E. \& G. Vazzoler. 1980. Método gráfico e estimativa de índice alimentar aplicado no estudo de alimentação de peixes. Boletim do Instituto Oceanográfico, 29: 205-207.

Krumme, U., U. Saint-Paul \& H. Rosenthal. 2004. Tidal and diel changes in the structure of a nekton assemblage in small intertidal mangrove creeks in northern Brazil. Aquatic Living Resources, 17: 215-229.

Leão, M. M. \& M. F. Carvalho. 2005. Tabela Brasileira de Composição de Alimentos: uma contribuição do setor saúde para promoção da segurança alimentar e nutricional no Brasil. Pp. 13-23. In: Salay, E. (Org.). Composição de alimentos: uma abordagem multidisciplinar. Campinas, Núcleo de Estudos e Pesquisas em Alimentação - NEPA UNICAMP. v1.

Lowe-McConnell, R. H. 1999. Estudos ecológicos de comunidades de peixes tropicais. São Paulo, Edusp, 534p. Tradução: Vazoller, A. E. A. de M., A. A. Agostinho \& P. T. M. Cunningham. Título original: Ecological studies in tropical fish communities.

MacArthur, R. H. \& E. R. Pianka. 1966. On optimal use of a patchy environment. The American Naturalist, 100: 603-609.

Machado, J. 2008. O município de Abaetetuba: geografia física e dados estatísticos. Abaetetuba, Edições Alquimia, 24p.

Maia, L. A. \& F. P. Chalco. 2002. Produção de frutos de espécies da floresta de várzea da Amazônia Central importantes na alimentação de peixes. Acta Amazonica, 32: 45-54.

Masdeu, M., F. T. Mello, M. Loureiro \& M. Arim. 2011. Feeding habits and morphometry of Iheringichthys labrosus (Lütken, 1874) in the Uruguay River (Uruguay). Neotropical Ichthyology, 9: 657-664.

Mazzoni, R., C. F. Rezende \& L. R. Manna. 2010. Feeding ecology of Hypostomus punctatus Valenciennes, 1840 (Osteichthyes, Loricariidae) in a costal stream from Southeast Brazil. Brazilian Journal of Biology, 70: 569-574.

Morton, R. M., B. R. Pollock \& J. P. Beumer. 1987. The occurrence and diet of fishes in a tidal inlet to a saltmarsh in southern Moreton Bay, Queensland. Australian Journal of Ecology, 12: 217-237.

Novakowski, G. C., N. S. Hahn \& R. Fugi. 2008. Diet seasonality and food overlap of the fish assemblage in a pantanal pond. Neotropical Ichthyology, 6: 567-576.

Peel, M. C., B. L. Finlayson \& T. A. McMahon. 2007. Updated world map of the Köppen-Geiger climate classification. Hydrology Earth System Sciences, 11: 1633-1644.
Pilati, R., I. F. Andrian \& J. W. P. Carneiro. 1999. Desempenho germinativo de sementes de Cecropia pachystachya trec. (Cecropiaceae), recuperadas do trato digestório de Doradidae, Pterodoras granulosus (Valenciennes, 1883), da planície de inundação do alto rio Paraná. Interciencia, 24: 381-388.

Pollux, B. J. A. 2011. The experimental study of seed dispersal by fish (ichthyochory). Freshwater Biology, 56: 197-212.

Ringuelet, R. A., R. H. Arámburu \& A. A. Arámburu. 1967. Los peces argentinos de agua dulce. La Plata, Comisión de Investigaciones Científicas de la Provincia de Buenos Aires, $602 p$.

Ruppert, E. E., R. S. Fox \& R. D. Barnes. 2005. Zoologia dos invertebrados: uma aboradagem funcional evolutiva. $7^{\mathrm{a}} \mathrm{ed}$. São Paulo, Roca, 1145p.

Sabaj, M. H. \& C. J. Ferraris, Jr. 2003. Family Doradidae (Thorny catfishes). Pp. 456-469. In: Reis, R. E., S. O. Kullander \& C. J. Ferraris, Jr. (Orgs.). Check list of the freshwater fishes of South and Central America. Porto Alegre, Edipucrs.

Sampaio, M. B. \& L. R. Carrazza. 2012. Manual tecnológico de aproveitamento integral do fruto e da folha do Buriti (Mauritia flexuosa). Brasília, D.F., Instituto Sociedade, População e Natureza (ISPN), 80p.

Santos, G. M. dos, B. de Mérona, A. A. Juras \& M. Jégu. 2004. Peixes do baixo rio Tocantins: 20 anos depois da Usina Hidrelétrica Tucuruí. Brasília, D. F., Eletronorte, 215p.

Santos, G. M. dos, E. J. G. Ferreira \& J. A. S. Zuanon. 2006. Peixes comerciais de Manaus. Manaus, Ibama/AM, Próvarzea, 141p.

Sioli, H. 1984. The Amazon and its main affluents: hydrography, morphology of the river courses, and river types. Pp. 127-165. In: Sioli, H. (Ed.). The Amazon: limnology and landscape ecology of a mighty tropical river and its basin. Dordrecht, The Netherlands, DRW. Junk Publishers.

Souza-Stevaux, M. C., R. R. B. Negrelle \& V. Citadini-Zanette. 1994. Seed dispersal by the fish Pterodoras granulosus in the Paraná River Basin. Brazil. Journal of Tropical Ecology, 10: 621-626.

Stevens, P. W., M. F. D. Greenwood, C. F. Idelberger \& D. A. Blewett. 2010. Mainstem and backwater fish assemblages in the Tidal Caloosahatchee River: implications for freshwater inflow studies. Estuaries and Coasts, 33: 1216-1224.

Waldhoff, D., U. Saint-Paul \& B. Furch. 1996. Value of fruits and seeds from the floodplain forests of Central Amazonia as food resource for fish. Ecotropica, 2: 143-156.

Winemiller, K. O. 1989. Ontogenetic diet shifts and resource partitioning among piscivorous fishes in the Venezuelan ilanos. Environmental Biology of Fishes, 26: 177-199.

Winemiller, K. O. \& D. B. Jepsen. 1998. Effects of seasonality and fish movement on tropical river food webs. Journal of Fish Biology, 53(suppl. A): 267-296.

Wolff, L. L., V. Abilhoa, F. S. A. Rios \& L. Donatti. 2009. Spatial, seasonal and ontogenetic variation in the diet of Astyanax aff. fasciatus (Ostariophysi: Characidae) in an Atlantic Forest river, Southern Brazil. Neotropical Ichthyology, 7: 257-266.

Zavala-Camin, L. A. 1996. Introdução aos estudos sobre alimentação natural em peixes. Maringá, Eduem, 129p.

Submitted January 22, 2013 Accepted January 16, 2015 by Fernando Pelicice Published June 30, 2015 